\title{
The truth about English?
}

There they are, all datelined 1997: David Crystal's English as a Global Language (Cambridge); John Honey's Language is Power: The Story of Standard English and its Enemies (Faber); and David Graddol's The Future of English? A guide to forecasting the popularity of the English Language in the 21st century (British Council: see also p. 61). And following Graddol is the BC's GEN - Global English Newsletter: Monitoring the changing role of English in the world, whose first issue emerged into cyberspace in November. A free updating service for the book, GEN is 'designed to encourage informed and constructive debate about the social, educational, political and economic consequences... of the spread of English'. (For further details, see p.61.)

This is a particularly rich and fertile time for books about English - maybe too rich and fertile? Or maybe just inevitable. More people than ever are using it and so more people are trying to catch its essence in print. But what intrigues me is how differently each of the writers does it, and how successfully - yet also how the essence of the thing can never quite be caught.

Take Crystal with his incredible last sentences: "If there is a critical mass, does this mean that the emergence of a global language is a unique event, in evolutionary terms? It may be that English, in some shape or form, will find itself in the service of the world community forever.' Or Honey's: 'All over the world, and in the very heart of our own [British] society, the disadvantaged and the oppressed are struggling to make themselves heard. This book has attempted to identify some of the forces which stand in their way, and some of the means available to them to regain their rightful voice.' Or Graddol's: 'So we must not be hypnotised by the fact that this [global] elite will speak English: the more significant fact may be that, unlike the majority of present-day native English speakers, they will also speak at least one other language - probably more fluently and with greater cultural loyalty.' It's worth tracing how each writer arrived at each closing statement.

Tom McArthur

The editorial policy of English Today is to provide a focus or forum for all sorts of news and opinion from around the world. The points of view of individual writers are as a consequence their own, and do not reflect the opinion of the editorial board. In addition, wherever feasible, ET generally leaves unchanged the orthography (normally British or American) and the usage of individual contributors, although the editorial style of the journal itself is that of Cambridge University Press. 